Orbis Tertius, vol. XXIV, $\mathrm{n}^{\circ}$ 29, e117, mayo-octubre 2019. ISSN 1851-7811

Universidad Nacional de La Plata

Facultad de Humanidades y Ciencias de la Educación

Centro de Estudios de Teoría y Crítica Literaria

\title{
Luciana Del Gizzo, Volver a la vanguardia: El invencionismo y su deriva en el movimiento poesía buenos aires (1944-1963). Buenos Aires, Aluvión, 2018, Beta Hispanismo, 262 páginas
}

Volver a la vanguardia... parte de una pregunta que no se pierde de vista a lo largo de las casi cuatrocientas páginas del libro y los casi veinte años que comprenden el período analizado: ¿es posible una vanguardia a mediados de siglo XX?; ¿es posible ser vanguardista después de la vanguardia?, ¿llamarse a sí mismos de esa manera? De ser así, ¿cuáles son las condiciones para que un efecto comparable a lo que una vanguardia produce tenga lugar? Los alcances de esa indagación están señalados por dos hitos que fundamentan el recorte temporal elegido: la salida del número único de Arturo. Revista de artes abstractas en 1944, donde participaron artistas y poetas que luego integrarían otros movimientos, como Arte Madí, Perceptismo y Arte Concreto Invención, en el marco del cual Tomás Maldonado y Edgar Bayley urdieron las ideas principales del invencionismo; y el único volumen de poesía que editó el Instituto Di Tella, en 1963, titulado Poesía argentina, donde se incluyó a tres poetas del grupo poesía buenos aires ${ }^{1}$ - Raúl Gustavo Aguirre, Edgar Bayley y Rodolfo Alonso- y que, según Del Gizzo “abre otra etapa en el arte y la poesía porteñas” (p. xii). Lo que sucedió entre uno y otro hito fue la conformación de un movimiento artístico-poético, devenido al poco tiempo estrictamente poético, que se dio a sí mismo el nombre de "invencionista” y luego abandonó los rótulos para integrar una comunidad más amplia en la revista poesía buenos aires, siempre dirigida por Raúl Gustavo Aguirre, con codirectores que fueron variando a lo largo de los diez años la publicación. ¿Qué podría significar para esos integrantes lanzar una revista donde la portada, antes que imágenes, daba a leer frases como "nunca dejaremos la vanguardia" $\left(1951, n^{\circ} 5\right)$ ? Analizar esa ambición es el objeto de Luciana Del Gizzo en este libro. Nos muestra, entonces, que "vanguardia" implicaba tanto el rechazo de la gramática, y escribir en cambio sin mayúsculas ni signos de puntuación, como el rechazo a las distinciones entre temas de tenor poéticos y temas vulgares, a partir de lo cual era posible transformar las "figuraciones poéticas" - "conjunto de reglas que determinan lo que se considera poesía” (p. 39) - de mediados de siglo XX en Argentina.

El libro recupera dos anécdotas que permiten imaginar algo de lo que se ponía en juego con la ambición de ser vanguardistas en los años cincuenta. En la fundación de la revista poesía buenos aires hay un robo, posibles piñas y una noche de bar. Cuando a fines de los años cuarenta Aguirre y Jorge Enrique Móbili se proponen hacer una publicación dedicada exclusivamente a la poesía, deciden que es imprescindible contar con la colaboración de Edgar Bayley y Juan Carlos Lamadrid, a quienes admiraban como verdaderos vanguardistas, pero se sentían intimidados para convencerlos. Entonces evaluaron que lo mejor era afrontar la situación en el bar a donde solía ir Lamadrid:

le dimos vino y lo dejamos hablar del boxeador Justo Suárez, “Torito”. "Dale más vino”, le decía yo a Aguirre. Aguirre era un tipo pulcro, medido, coherente y yo, serio, le decía: "Dale más vino”. En un momento, notando los originales debajo del sobretodo de pelo de camello que tenía Lamadrid, Aguirre me dijo por lo bajo: "Los poemas". Entonces le dije a Aguirre: "Afanáselos”. Aguirre se puso blanco como un papel. Y nos afanamos los poemas. Al otro día se armó un lío bárbaro del que se enteró todo Buenos Aires. Lamadrid decía: "Me mamaron en una cantina y me afanaron el libro". (Reportaje a Jorge Enrique Móbili, en Fondebrider, Freidemberg y Samoilovich: 14, citado en p. 156). 
Ese robo constituye una doble identidad, que Luciana Del Gizzo nombra como "autorización fraudulenta": la aventura nocturna, la fantasía de ilegalidad, la poesía como contrabando, por un lado; y la seriedad de cumplir el propósito deseado, por otro. Tiempo después, ya en 1954, Aguirre organizó un evento titulado Presentación de la Nueva Poesía Argentina: la generación última, en el teatro Florencio Sánchez, en torno al especial de poesía buenos aires sobre "poetas de hoy" y a la edición de Antología de una poesía nueva. Según Francisco Urondo, a la salida, Oliverio Girondo dijo, tal vez no sin malicia, "Este Aguirre es milagroso, ¿cómo habrá hecho para encontrar 40 poetas en Buenos Aires?”. El robo y la exuberancia de reunir a cuarenta poetas proponen una forma especial de pensar la relación entre la vanguardia entendida como modernización cultural, y el ámbito local experimentado como carencia. "Vanguardistas apócrifos o por apropiación", dice Del Gizzo, los jóvenes de poesía buenos aires inventan las condiciones para su emergencia. O más bien, me gustaría agregar, espectacularizan la invención de esas condiciones en el gesto performático y ficticio que contiene toda vanguardia.

Estas anécdotas o escenas tienen como contraparte lo que Del Gizzo analiza como "lenguaje poético perimido que, tanto por parte de los círculos conservadores como por parte de los peronistas reformadores en lo social, abarcaba todo el espectro de producción poética" (p. xxii). El deseo de "no abandonar nunca la vanguardia" se analiza en relación al "estado de las figuraciones de lo artístico en la coyuntura en que se procura su quiebre” (p.x); la propuesta de Sur como la de Mundo peronista (marcadas por el soneto, la métrica exacta, las figuras retóricas clásicas y la conformación de imágenes figurativas o representacionales) resultaban, para los jóvenes invencionistas, igualmente atrasadas en relación al tipo de imagen que buscaban impulsar desde sus páginas ("poesía desmantelada”, "sin contraseñas para el prodigio”, "poesía sin espejos”, "poesía sin fondo"), y es en ese estado del arte donde irrumpe, para la autora, la propuesta poética del invencionismo y la revista poesia buenos aires.

Así, en el capítulo I, Un conjuro para la vanguardia, reconfigura este término ya "no como una categoría estética de ruptura y novedad", sino como una "estética del umbral" que "explicita la intención de intervenir sobre lo que ya no es, al tiempo que ofrece en potencia aquello que todavía no ha tomado forma” (p. 159) y es analizado como un pliegue histórico, no sucesivo ni intercambiable - es decir, no habría una generación de vanguardia que sucedió a una generación de la década del cuarenta-, tensionado por sus propias limitaciones de novedad. En el capítulo II, El fin de la elocuencia, explica el proceso por el cual el invencionismo buscó "desarmar las retóricas anquilosadas" que "asociaban la poesía con el uso insistente de la elocuencia, entendida como esa zona del lenguaje vinculada al buen decir y al habla apropiada, pero que también acude a ciertos recursos para conmover o persuadir" (pp.41-42). En esa indeterminación se opone al tipo de solidez con que se había pensado la generación anterior: "El grupo del 40 nace a la vida literaria o, mejor dicho, a la historia literaria, con serios y conscientes afanes de permanencia. Tan imbuidos estaban en su propia importancia, que en seguida empezaron ellos mismos a historiarse" (Soler Cañas citado en p. 55), ya que por el contrario,

el cuestionamiento del estatus del arte que ejercieron hizo que muchas [vanguardias] resultaran evanescentes y, en algunos casos, que estuvieran dispuestas a resignar su trascendencia para alcanzar sus objetivos de transformación artística (p. ix).

Ente los capítulos III y VI, la autora lee los años que van de Arturo a Conjugación de Buenos Aires (1944-1951) y de esta última a poesía buenos aires (1950-1960), en la trama de un movimiento donde identifica una primera etapa de "experimentación con nuevos materiales de la lengua" y otra de y "apertura" o "ampliación" de los criterios estéticos que se debió a la búsqueda de una poesía articulada con la cotidianeidad, o, en palabras del mismo Edgar Bayley, una poesía que no se redujera al poema. En ese marco, particulariza las tensiones entre el carácter singular de lo poético en cada miembro de la revista - todos poetas- en relación con el carácter colectivo de la misma. Esa primera etapa de mayor experimentación, analizada en los capítulos III y IV - Contra la representación y La mecánica poética - es la que habría permitido "desarmar el 
lenguaje anquilosado de las retóricas hegemónicas" y correlativamente mantener bajo sospecha toda muestra de representación o figuración. Son los años de conformación del movimiento, de la "competencia por la abstracción" y la búsqueda de la "gute forme” maxbillieana como síntesis del triunfo anti-representacional y materialismo dialéctico; es decir, una salida revolucionaria para el arte y la poesía que no implicaba la recaída en modelos figurativos, miméticos, donde el tema tuviera preponderancia por sobre las formas o los procedimientos. En los capítulos V y VI se aborda una segunda etapa, ya con la revista poesía buenos aires, que daría cuenta de un momento de ampliación que se funda en el texto inicial de Edgar Bayley titulado "invencionismo", donde, según Del Gizzo, "planteaba que la distancia infranqueable del lenguaje solo encontraría como instancia mediadora la "conciencia de la libertad de asignar sentidos que se unifican en el sentido común"”. Este enfoque implicaba el relajamiento de la actitud rupturista de la vanguardia, porque en lugar de posicionarse en relación a una tradición específica para reconfigurarla, "se enrola en una idea más amplia del pasado, que entiende como un elemento que subsistía en un devenir":

Una distancia como la que va del cuerpo al espíritu es la que caracteriza el trayecto que recorrió la noción de experiencia estética en estas figuraciones de lo poético: desde aquel 'desplazamiento de valores de sensibilidad ejercido por una imagen' (Bayley, 1944, p.7) que el invencionismo inicial señalaba como causa de la novedad de la obra de arte y de su capacidad para expresar el lazo entre individuo y sociedad, hasta esta potencia de liberar el espíritu e independizarlo para favorecer vínculos humanos genuinos.

No se trata, sin embargo, de algo tan esquemático como "dos etapas" demarcables, ya que, señala Del Gizzo, las ideas de liberación y de conciencia permanecen como elementos o valores comunes a todo el periplo del movimiento. A su vez, en los capítulos dedicados más especialmente a la lectura de la revista poesía buenos aires, analiza la convivencia de las ideas románticas con las invencionistas, como la atribución de facultades excepcionales al poeta, la disposición de trascendencia a partir de la capacidad del poeta para comprender tanto lo inmediato como lo infinito, que convivían con otras como la búsqueda de un vínculo con lo cotidiano o "una poesía desmantelada”, como afirmaba Aguirre desde los primeros números de poesía.

Estos movimientos, entre el poeta como mito de lo trascendente y la búsqueda de una poesía en minúsculas, depurada de las ampulosidades que consideraban "aristocratizantes", se producen al amparo de lo que Del Gizzo caracteriza como "comunidad", suerte de refugio donde convivían las singularidades de quienes participaban en la revista como colaboradores o directores, miembros del grupo y un consejo de redacción entendido como colectivo. Esa dinámica imprimió, a su vez, transformaciones en la "lógica del manifiesto", ya que las declaraciones programáticas se hacían en forma individual "sin el encorsetamiento de reglas dogmáticas", y en un lenguaje que fuera él mismo poético, donde "un acto de indeterminación” diluía la estabilidad de los recursos formales más o menos estabilizados que caracterizan el género que las vanguardias legaron a la historia abierta del arte y la literatura. Volver a la vanguardia... nos pone en el lugar donde emerge el gesto capaz de leer lo nuevo en lo viejo, retomar desde la novedad que quedó inaudible y suspendida, para expandir siempre un poquito más lo que es posible decir y mirar.

Verónica Stedile Luna

\section{Notas}

1 El uso de la minúscula corresponde al modo de inscripción tipográfica del movimiento. Dice Del Gizzo en una aclaración: "Utilizaré letra redonda para referirme al grupo de poetas aglutinados en la revista poesía buenos aires y cursiva para referirme a la publicación específicamente. En todos los casos el nombre aparecerá sin mayúsculas, respetando la grafía original como marca vanguardista” (p. xii). 